\title{
Reverse Osmosis Polyamide Thin Film Nanocomposite Membranes for Water Desalination: A Study
}

\author{
Ahmed Al Mayyahi ${ }^{1}$, Hamid Al Asadi ${ }^{2}$ \\ ${ }^{1}$ University of Missouri, Columbia, MO 65211, USA \\ ${ }^{2}$ University of Basra, Basra, 61004, Iraq
}

*Corresponding Author: Ahmed Al Mayyahi, 1University of Missouri, Columbia, MO 65211, USA

\begin{abstract}
Reverse osmosis (RO) desalination is one of the well-known technologies for water purification. Since its development, many studies have been devoted to improve this technique. Nanostructured reverse osmosis membrane is expected to play an important role in water desalination. The main objective of this study is to highlight the most important achievements in reverse osmosis membrane technology.
\end{abstract}

Keywords: Thin Film Nanocomposite (TFN); Reverse Osmosis (RO); Desalination; Nanoparticles (NPs).

\section{INTRODUCTION}

Lack of clean water resources is a grand issue in modern society [1,2]. Water desalination represents a real solution to produce clean water for human consumption and industrial sectors [3]. Because of its high efficiency, reverse osmosis (RO) is considered as the most important desalination technology [4,5]. Thin film nanocomposite membrane has become a frequently selected RO membrane [6].This membrane is prepared by interfacial polymerization (IP) process and incorporation of nanoparticles into polyamide (PA) active layer with the aim of improving membrane characteristics including the hydrophilicity and surface charge. The term TFN membrane was first introduced by Hoek and his coworkers in 2007 [7]. In their work, they used zeolite NaA nanoparticles as filler in PA active layer during interfacial polymerization between m-phenylenediamine (MPD) and trimesoyl Chloride (TMC). Remarkable enhancement in water flux was achieved by embedding zeolite NaA nanoparticle without sacrificing membrane separation efficiency. This improvement was ascribed to hydrophilic property of zeolite nanoparticles which facilitate water solubilization and diffusion through the membrane.

Table 1 summarized the performance of RO TFN membrane that studyed in research publications. Next section is presented the recent scientific and technological advances in the development of nanocomposite membranes for water treatment.

\section{Permeability and Selectivity}

Embedding hydrophilic nanoparticles into the polyamide layer of the composite membrane lead to significant enhancement in the membrane performance including water flux and salt rejection. As it mentioned earlier, zeolite $\mathrm{NaA}$ is the first nanomaterial that has been used to improve membrane water flux due to its superior hydrophilicity, high negative surface charge, and internal pores which facilitate water adsorption across the membrane [7].

Lind and his coworkers [9] investigated the effect of nanoparticles size on membrane performance using different size of zeolite nanoparticles. Smaller nanoparticles produced higher water flux due to its large pores, on the other hand larger nanoparticles produce better surface properties. This study suggested that nanoparticles size is an important factor needs to be considered while fabricating PA nanocomposite membrane.

In addition to zeolite, different nanomaterials have been used to modify membrane performance; all mentioned in table 1 . 
Table1. Summary of thin-film nanocomposite membranes

\begin{tabular}{|c|c|c|c|c|}
\hline Nanofiller & $\begin{array}{l}\text { PA Layer } \\
\text { monomers }\end{array}$ & Substrate & performance of TFN & Ref. \\
\hline Zeolite $\mathrm{NaA}$ & MPD-TMC & PSU & $\begin{array}{l}\text { Water flux increased from } 2.5 * 10^{12} \text { to } 3.9 \\
* 10^{12} \mathrm{mPa}^{-1} \mathrm{~s}^{-1} \text { without compromising salt } \\
\text { rejection }(94 \%) \text { by increasing concentration of } \\
\text { nanoparticles from } 0 \text { t0 } 0.4 \mathrm{wt} \% \text {. }\end{array}$ & [7] \\
\hline $\begin{array}{l}\text { Zeolite } \mathrm{NaA} \\
\mathrm{AaA}\end{array}$ & MPD:TEA-TMC & PSU & $\begin{array}{l}\text { Both AgA-TFN and NaA-TFN membranes } \\
\text { exhibited higher water flux than that of TFC } \\
\text { membrane. No change in salt rejection was } \\
\text { observed. Less accumulation of bacterial cells } \\
\text { on AgA-FTN and NaA-TFN membranes } \\
\text { compared to TFC membrane }\end{array}$ & {$[8]$} \\
\hline $\begin{array}{l}\text { Different Sized } \\
\text { Zeolite }\end{array}$ & $\begin{array}{l}\text { MPD:TEA:SLS:IPA- } \\
\text { TMC }\end{array}$ & PSU & $\begin{array}{l}\text { Changes in interfacial polymerization } \\
\text { chemistry can be used to tune PA TFN } \\
\text { membrane properties. Smaller zeolite NPs } \\
\text { produced greater improvement in membrane } \\
\text { performance than that of bigger zeolite NPs. }\end{array}$ & [9] \\
\hline Silica & MPD-TMC & PSU & $\begin{array}{l}\text { By increasing silica concentration, more } \\
\text { thermally membrane produced. Excellent } \\
\text { water flux was observed for TFN membrane } \\
\text { containing } 1-2 \mathrm{wt} \% \text {. }\end{array}$ & {$[10]$} \\
\hline MWCNTs & MPD-TMC & PSU & $\begin{array}{l}\text { Both water flux and salt rejection decreased } \\
\text { from } 18 \text { to } 12 \mathrm{~L} / \mathrm{m} \text { hr and } 98 \text { to } 92.2 \mathrm{wt} \% \text {, } \\
\text { respectively, by increasing concentration of } \\
\text { MWCNTs from } 0 \text { to } 1 \mathrm{wt} \% \text {. MWCNTs } \\
\text { enhanced chlorine resistance of TFN } \\
\text { membrane. }\end{array}$ & {$[11]$} \\
\hline Zeolite LTA & $\begin{array}{l}\text { MPD-TMC-post } \\
\text { Treatment }\end{array}$ & PSU & $\begin{array}{l}\text { Post treatment with } \mathrm{NaOCl}, \mathrm{Na}_{2} \mathrm{~S}_{2} \mathrm{O}_{5} \text {, and } \\
\mathrm{NaHCO}_{3} \text { resulted in very high salt rejection } \\
99.4 \mathrm{wt} \% \text { and high water flux } 42 \mathrm{~L} / \mathrm{m} 2 \text {. } \\
\text { Defects and molecular sieving largely control } \\
\text { transport through zeolite-TFN membranes. }\end{array}$ & {$[12]$} \\
\hline F-Silica & MPD-TMC & PSU & $\begin{array}{l}\text { The water flux increased by increasing } \\
\text { concentration of NPs from } 0 \text { to } 0.4 \mathrm{wt} \% \text { with } \\
\text { little decrease in salt rejection. Thermally } \\
\text { stable membrane produced. }\end{array}$ & {$[13]$} \\
\hline F-MWCNTs & MPD-TMC & PSU & $\begin{array}{l}\text { Water permeability increased from } 25 \text { to } 70 \\
\mathrm{~L} / \mathrm{m}^{2} \mathrm{~h} \text { by increasing concentration of NPs } \\
\text { from } 0 \text { to } 0.1 \mathrm{wt} \% \text { while } \mathrm{NaCl} \text { rejection } \\
\text { dramatically decreased. Rough and } \\
\text { hydrophilic membrane produced. }\end{array}$ & [14] \\
\hline $\begin{array}{l}\text { Metal } \\
\text { alkokxide }\end{array}$ & MPD: SLS-TMC & PSU & $\begin{array}{l}\text { Three different type of Metal-alkokxide } \\
\text { (PhTES, BTESE, TTIP) used to prepared } \\
\text { TFNs, all three type show superior } \\
\text { performance in term of permeability. TTIP } \\
\text { and BTESE led to little decrease in salt } \\
\text { rejection while TTIP did not affect the } \\
\text { rejection. }\end{array}$ & {$[15]$} \\
\hline Zeolite $\mathrm{NaX}$ & MPD-TMC & PES & $\begin{array}{l}\text { Concentration of MPD and TMC significantly } \\
\text { affect membrane performance. The membrane } \\
\text { of high concentration of TMC }(0.15 \% \mathrm{w} / \mathrm{v}) \\
\text { and MPD }(3 \% \mathrm{w} / \mathrm{v}) \text { has the highest water flux } \\
50 \mathrm{~L} / \mathrm{m}^{2} \mathrm{hr} \text {, but lowest salt rejection }(94 \%) \text {. } \\
\text { Zeolite NPs increased membrane } \\
\text { hydrophilicity. }\end{array}$ & [16] \\
\hline iLSMM & MPD-TMC & PSU & $\begin{array}{l}\text { Different concentration of MPD, different } \\
\text { curing time, and different concentration of } \\
\text { NPs }(0-0.25) \text { used in preparation of twelve } \\
\text { TFN membranes. Water flux ranging from } 21 \\
\text { t0 } 42 \mathrm{l} / \mathrm{m}^{2} \mathrm{hr} \text { and salt rejection from } 86 \text { to } 97\end{array}$ & [17] \\
\hline
\end{tabular}




\begin{tabular}{|c|c|c|c|c|}
\hline & & & $\begin{array}{l}\% \text {. Present of iLSMM enhanced antifouling } \\
\text { properties of TFB membranes. }\end{array}$ & \\
\hline MCM-41 & MPD-TMC & PSU & $\begin{array}{l}\text { Water flux increased from } 28 \text { to } 46 \mathrm{~L} / \mathrm{m}^{2} \mathrm{hr} \text { by } \\
\text { increasing concentration of NPs from } 0 \text { to } 0.1 \\
\mathrm{wt} \% \text { while } \mathrm{NaCl} \text { rejection almost remain } \\
\text { constant }(79 \mathrm{wt} \%) \text {. Porous structure of NPs } \\
\text { plays important roles in creating short path for } \\
\text { water molecules. }\end{array}$ & {$[18]$} \\
\hline APQZ & MPD-TMC & PSU & $\begin{array}{l}\text { The resulting membrane has good mechanical } \\
\text { stability when tested under } 10 \text { bar. Water flux } \\
\text { increased from } 16 \text { to } 40 \mathrm{~L} / \mathrm{m}^{2} \mathrm{hr} \text { by increasing } \\
\text { concentration of NP from o to } 0.1 \mathrm{wt} \% \text {. }\end{array}$ & [19] \\
\hline $\begin{array}{l}\text { Zwitterion- } \\
\text { CNT }\end{array}$ & MPD-TMC & PES & $\begin{array}{l}\text { Water flux increased from } 11.85 \text { to } 48 \mathrm{~L} / \mathrm{m}^{2} \mathrm{hr} \\
\text { using } 20 \% \text { NPs, under } 350 \text { PSI. salt rejection } \\
\text { decreased little bit. }\end{array}$ & [20] \\
\hline $\begin{array}{l}\text { Carboxylic } \\
\text { MWNTs }\end{array}$ & MPD-TMC & PES & $\begin{array}{l}\text { The resulting membrane has good mechanical } \\
\text { properties. Charged NPs prevent formation of } \\
\text { biofouling layer on membrane surface. Water } \\
\text { flux increased to } 2140 \mathrm{~L} / \mathrm{m}^{2} \mathrm{hr} \text { under } 100 \text { PSI. } \\
\text { Applying electrical potential to the membrane } \\
\text { does not change its transport properties. }\end{array}$ & [21] \\
\hline $\begin{array}{l}\text { Zeolite } \\
\text { (Silicate-1) }\end{array}$ & MPD-TMC & PSU & $\begin{array}{l}\text { The resultant membrane has outstanding } \\
\text { chemical stability in comparison with NaX- } \\
\text { Zeolite mixed membrane. Water flux of } \\
\text { silicate-zeolite }\left(65 \mathrm{~L} / \mathrm{m}^{2} \mathrm{hr} \text { at } 0.05 \mathrm{wt} \%\right) \text { is } \\
\text { higher than that of } \mathrm{NaX}\left(35 \mathrm{~L} / \mathrm{m}^{2} \mathrm{hr} \text { at } 0.1\right. \\
\text { wt\%) due to larger pores size and higher } \\
\text { water diffusion rate of silicate zeolite. Both } \\
\text { membrane have good salt rejection. }\end{array}$ & {$[22]$} \\
\hline Zeolite $\mathrm{NaA}$ & MPD-TMC & PSU & $\begin{array}{l}\text { Good water flux achieved }\left(46.5 \mathrm{~L} / \mathrm{m}^{2} \mathrm{hr}\right) \text { by } \\
\text { adding NPs in organic phase. high salt } \\
\text { rejection }(97 \%) \text { by adding NPS in aqueous } \\
\text { phase. }\end{array}$ & [23] \\
\hline $\begin{array}{l}\text { Aminated } \\
\text { Zeolite }\end{array}$ & $\begin{array}{l}\text { MPD:PES:TEA- } \\
\text { TMC }\end{array}$ & PSU & $\begin{array}{l}\text { Adding PES and TEA to MPD-nanoparticle } \\
\text { solution increased water flux from } 23.2 \text { to } \\
37.8 \mathrm{~L} / \mathrm{m}^{2} \mathrm{hr} \text { without compromising salt } \\
\text { rejection ( } 98 \%) \text {. The membrane showed good } \\
\text { chlorine resistance. }\end{array}$ & {$[24]$} \\
\hline Zeolite A & MPD-TMC & PSU & $\begin{array}{l}\text { The resultant membrane exhibited superior } \\
\text { interfacial properties and separation } \\
\text { performance including high water flux, } \\
\text { observed salt rejection and enhanced } \\
\text { resistance to irreversible flux decline due to } \\
\text { physical compaction }\end{array}$ & [25] \\
\hline $\begin{array}{l}\text { Mesoporous } \\
\text { silica }\end{array}$ & MPD-TMC & PSU & $\begin{array}{l}\text { Water flux increased from } 19 \text { to } 53 \mathrm{~L} / \mathrm{m}^{2} \mathrm{hr} \text {. } \\
\text { salt rejection remain constant } 97 \%\end{array}$ & [26] \\
\hline HBP-g-silica & MPD: aPES-TMC & PSU & $\begin{array}{l}\text { Water flux increased from } 22.1 \text { to } 34.4 \mathrm{~L} / \mathrm{m}^{2} \\
\text { hr while the salt rejection decreased from } 98 \\
\text { to } 97.7 \% \text {. The membrane showed better } \\
\text { chlorine resistance. }\end{array}$ & [27] \\
\hline $\begin{array}{l}\text { Aluminosilicate } \\
\text { CNTs }\end{array}$ & MPD-TMC & PSU & $\begin{array}{l}\text { Water flux increased from } 13 \text { to } 23 \mathrm{~L} / \mathrm{m}^{2} \mathrm{hr} \\
\text { under low pressure while salt rejection almost } \\
\text { remained constant } 97.5 \% \text {. }\end{array}$ & [28] \\
\hline F-MWCNTs & MPD-TMC & PSU & $\begin{array}{l}\text { Water flux increased from } 14.86 \text { to } 28.05 \\
\mathrm{~L} / \mathrm{m}^{2} \mathrm{hr} \text { while salt rejection slightly deceased } \\
\text { to } 90 \% \text {. The membrane showed better } \\
\text { antifouling and antioxidant properties. }\end{array}$ & [29] \\
\hline HNTs & MPD-TMC & PSU & $\begin{array}{l}\text { Water flux increased from } 18 \text { to } 36.1 \mathrm{~L} / \mathrm{m}^{2} \mathrm{hr} \\
\text { while salt rejection decreased } 94 \text { to } 93 \% \text {. The } \\
\text { membrane has enhanced fouling properties. }\end{array}$ & [30] \\
\hline OA-silica & MPD-TMC & PSU & $\begin{array}{l}\text { The OA modified-silica PA membrane } \\
\text { produced higher salt rejection }(98 \%) \text { in }\end{array}$ & [31] \\
\hline
\end{tabular}




\begin{tabular}{|c|c|c|c|c|}
\hline & & & $\begin{array}{l}\text { comparison to unmodified silica PA } \\
\text { membrane }(95 \%) \text { while maintain its high } \\
\text { water flux around } 49 \mathrm{~L} / \mathrm{m}^{2} \mathrm{hr} \text {. }\end{array}$ & \\
\hline Clay & MPD-TMC & PSU & $\begin{array}{l}\text { The water flux increased from } 36.6 \text { to } 51 \mathrm{~L} / \mathrm{m}^{2} \\
\text { hr by adding } 0.1 \mathrm{wt} \% \text { NPs without } \\
\text { compromising salt rejection (around } 99 \% \text { ). } \\
\text { Modified membrane exhibited significant } \\
\text { antifouling properties. }\end{array}$ & [32] \\
\hline Graphene- $\mathrm{TiO}_{2}$ & MPD-TMC & PSU & $\begin{array}{l}\text { Both water flux and salt rejection increased } \\
\text { from } 34 \text { to } 51 \mathrm{~L} / \mathrm{m}^{2} \mathrm{hr} \text { and } 97 \text { to } 99 \% \text { by } \\
\text { adding } 0.02 \mathrm{wt} \% \text { NPs. Antifouling properties } \\
\text { and anti-chlorine resistance were enhanced. }\end{array}$ & [33] \\
\hline $\mathrm{HN}_{2}$-TNTs & MPD-TMC & PSU & $\begin{array}{l}\text { Both water flux and salt rejection increased } \\
\text { from } 19 \text { to } 36 \mathrm{~L} / \mathrm{m}^{2} \mathrm{hr} \text { and } 94 \text { to } 96 \% \text { by } \\
\text { adding } 0.05 \mathrm{wt} \% \text { NPs. Antifouling properties } \\
\text { and anti-chlorine resistance were enhanced. } \\
\text { Modified membrane exhibited significantly } \\
\text { mitigate BSA fouling and achieved good } \\
\text { water flux recovery after simple rinsing. }\end{array}$ & [34] \\
\hline $\begin{array}{l}\text { Graphene } \\
\text { Oxide }\end{array}$ & MPD-TMC & PSU & $\begin{array}{l}\text { The water flux increased from } 1.8 \text { to } 22 \mathrm{~L} / \mathrm{m}^{2} \\
\text { hr by increasing NPs concentration to } 0.20 \\
\text { wt\% (working under } 217 \text { psi). } \mathrm{NaCl} \text { rejection } \\
\text { almost remain constant (above } 80 \% \text { ). } \\
\text { Modified TFN exhibited excellent anti-fouling } \\
\text { properties against BSA and HA }\end{array}$ & [35] \\
\hline $\mathrm{Al}-\mathrm{ZnO}$ & MPD-TMC & PSU & $\begin{array}{l}\text { Water flux increased from } 26 \text { to } 32 \mathrm{~L} / \mathrm{m}^{2} \mathrm{hr} \text { by } \\
\text { increasing NPs concentrations to } 0.5 \mathrm{wt} \% \text {. salt } \\
\text { rejection decreased little bit then return to its } \\
\text { original value } 98 \% \text {. }\end{array}$ & [36] \\
\hline MCM-48 & MPD-TMC & PSU & $\begin{array}{l}\text { The NPs embedded first in organic phase: } \\
\text { water flux increased from } 34 \text { to } 40 \mathrm{~L} / \mathrm{m}^{2} \mathrm{hr} \\
\text { (salt rejection remain constant } 95 \% \text { ). Second } \\
\text { in aqueous phase water flux increased from } 24 \\
\text { to } 68 \mathrm{~L} / \mathrm{m}^{2} \mathrm{hr} \text { (salt rejection decreased from } 97 \\
\text { t0 } 80 \% \text { ). }\end{array}$ & [37] \\
\hline $\begin{array}{l}\text { Graphene } \\
\text { Oxide }\end{array}$ & MPD-TMC & PSU & $\begin{array}{l}\text { Water flux increased from } 39 \text { to } 60 \mathrm{~L} / \mathrm{m}^{2} \mathrm{hr} \text { by } \\
\text { increasing NPs concentrations to } 0.015 \mathrm{wt} \% \\
\text { while salt rejection decreased from } 95.5 \text { to } 93 \\
\% \text {. Working pressure } 300 \mathrm{psi}\end{array}$ & [38] \\
\hline
\end{tabular}

Another significant enhancement in membrane water flux was accomplished by Yin and his coworkers [18] upon incorporating of MCM-41 silica nanoparticles. The enhanced water flux was ascribed to high hydrophilicity of the embedded nanoparticles and the pores in the nanoparticles that provided additional channels for water to pass through.

\section{ChLORINE ReSiSTANCE}

It has been pointed out that the polyamide RO membranes have weak resistance to chlorine. When the PA membrane contacts with chlorine, $\mathrm{N}-\mathrm{H}$ in the amide bond (-NHCO-) is chlorinated and then hydrolyzed in water. Finally, the amine is changed into a quinoid structure and decomposed, causing failure in membrane performance [13]. Park et al [11] used acid functionalized MWCNTs to enhance PA membrane anti-chlorine properties. When MWCNTs were embedded into the PA layer, the membrane exhibited improved chlorine resistance. This can be ascribed to the reaction between hydroxylic groups in CNTs and amine groups in polyamide layer.

Because amide bonds are the main target of chlorine attack, introducing additional amide bonds or amino groups to the membrane seems to be a reasonable strategy to protect PA cross-linking structure. So, Chun et al [27] introduced polyamide modified silica NPs into the polyamide layer. Results showed that the modified composite membrane demonstrated better chlorine resistance. This ascribed to introduction of extra amide groups to membrane surface which mitigate the hydrogenchlorine interaction at the PA structure. 


\section{ORGANiC AND MicROBiologicAl Fouling}

Membrane fouling is defined as the deposition of undesired substance on membrane surfaces causing membrane performance failure. Organic fouling of composite membranes is the primary cause for the declination in membrane performance [39]. Hence, many studies are focused on fabricating a membrane with better anti-fouling properties.

Kim and his coworkers [40] showed that the membrane hydrophilicity is related to fouling stability. In other words, increasing the membrane hydrophilicity resulted in a membrane with good antifouling properties. Rana et al [41] showed that introducing negatively charge nanoparticles to membrane surface could improve membrane antifouling properties by generating electrostatic repulsion force between membrane surface and negative foulants.

\section{CONCLUSION}

Reverse osmosis membrane technology witnessed a tremendous development in recent years. Although Incorporating of nanoparticles in membrane PA layer resulted in a membrane with significantly improved characteristic including water flux, salt rejection, and antifouling properties, several challenges are still need to be addressed such as relationship between water flux and salt rejection, effect of particle size on defecting membrane rejection barrier, and improve nanoparticle dispersion in membrane.

\section{REFERENCES}

[1] P. Marry, and E. Hoek, A review of water treatment membrane nanotechnologies, Energy and environment science 4 (2011) 1946-1971

[2] M. Elimelech, W.A. Phillip, The future of seawater desalination: energy, technology, and the environment, Science 333 (2011) 712-717

[3] J. Bremere, M. kennedy, A. Stickker, J. Schipper, How water scarcity will effect the growth in desalination market in the coming 25 years, Desalination 138 (2001) 7-9

[4] L. Malaeb, and G. Ayoub, Reverse osmosis technology for water treatment: State of the art review, Desalination, 276 (2011) 1-8

[5] Van der Bruggen, B.; Vandecasteele, C. Distillation vs. membrane filtration: Overview of process evolutions in seawater desalination. Desalination2002, 143, 207-218

[6] L.Y. Ng, A.W. Mohammad, C.P. Leo, N. Hilal, Polymeric membranes incorporated with metal/metal oxide nanoparticles: a comprehensive review, Desalination 308 (2013) 15-33.

[7] B.-H. Jeong, E.M.V. Hoek, Y. Yan, A. Subramani, X. Huang, G. Hurwitz, A. K. Ghosh, A. Jawor, Interfacial polymerization of thin film nanocomposites: a new concept for reverse osmosis membranes, $\mathrm{J}$. Membr. Sci. 294 (2007) 1-7.

[8] M.L. Lind, B.H. Jeong, A. Subramani, X. Huang, E.M.V. Hoek, Effect of mobile cation on zeolitepolyamide thin film nanocomposite membranes, J. Mater. Res. 24 (2009) 1624-1631.

[9] M.L. Lind, A.K. Ghosh, A. Jawor, X. Huang, W. Hou, Y. Yang, E.M.V. Hoek, Influence of zeolite crystal size on zeolite-polyamide thin film nanocomposite membranes, Langmuir 25 (2009) 10139-10145

[10] G.L. Jadav, P.S. Singh, Synthesis of novel silica-polyamide nanocomposite membrane with enhanced properties, J. Membr. Sci. 328 (2009) 257-267

[11] J. Park, W. Choi, S.H. Kim, B.H. Chun, J. Bang, K.B. Lee, Enhancement of chlorine resistance in carbon nanotube-based nanocomposite reverse osmosis membranes, Desalin. Water Treatment 15 (2010) 198 204.

[12] M.L. Lind, D.E. Suk, T.V. Nguyen, E.M.V. Hoek, Tailoring the structure of thin film nanocomposite membranes to achieve seawater RO membrane performance, Environ. Sci. Technol. 44 (2010) 8230-8235.

[13] G.L. Jadav, V.K. Aswal, P.S. Singh, SANS study to probe nanoparticle dispersion in nanocomposite membranes of aromatic polyamide and functionalized silica nanoparticles, J. Colloid Interface Sci. 351 (2010) 304-314.

[14] S. Roy, S.A. Ntim, S. Mitra, K.K. Sirkar, Facile fabrication of superior nanofiltration membranes from interfacially polymerized CNT-polymer composites, J. Membr. Sci. 375 (2011) 81-87.

[15] C. Kong, A. koushima, T. Kamada, T. Shintani, M. Kanezashi, T. Yoshioka, T. Tsuru, Enhanced performance of inorganic-polyamide nanocomposite membranes prepared by metal-alkoxide-assisted interfacial polymerization, J. Membr. Sci. 366 (2011) 382-388. 
[16] M. Fathizadeh, A. Aroujalian, A. Raisi, Effect of added NaXnano-zeolite into polyamide as a topthin layer of membrane onwater flux and salt rejection in a reverse osmosis process, J. Membr. Sci. 375 (2011) 8895

[17] D. Rana, Y. Kim, T. Matsuura, H.A. Arafat, Development of antifouling thin film-composite membranes for seawater desalination, J. Membr. Sci. 367 (2011) 110-118.

[18] J. Yin, E.S. Kim, J. Yang, B. Deng, Fabrication of a novel thin-film nanocomposite (TFN) membrane containing MCM-41 silica nanoparticles (NPs) for water purification, J. Membr. Sci. 423-424 (2012) 238246.

[19] Y. Zhao, C. Qiu, X. Li, A. Vararattanavech, W. Shen, J. Torres, C. Hélix-Nielsen, R. Wang, X. Hu, A.G. Fane, C.Y. Tang, Synthesis of robust and high performance aquaporin-based biomimetic membranes by interfacial polymerization-membrane preparation and RO performance characterization, J. Membr. Sci. 423-424 (2012) 422-428

[20] W.F. Chan, H.Y. Chen, A. Surapathi, M.G. Taylor, X. Shao, E. Marand J.K. Johnson, Zwitterion functionalized carbon nanotube/polyamide nanocomposite membranes for water desalination, ACS Nano 7 (2013) 5308-5319

[21] C.F. De Lannoy, D. Jassby, K. Gloe, A.D. Gordon, M.R. Wiesner, Aquatic biofouling prevention by electrically charged nanocomposite polymer thin film membranes, Environ. Sci. Technol. 47 (2013) 27602768.

[22] H. Huang, X. Qu, X. Ji, X. Gao, L. Zhang, H. Chen, L. Hou, Acid and multivalent ion resistance of thin film nanocomposite RO membranes loaded with silicalite-1 nanozeolites, J. Mater. Chem. A 1 (2013) 11343-11349.

[23] H. Huang, X. Qu, H. Dong, L. Zhang, H. Chen, Role of NaA zeolites in the interfacial polymerization process towards a polyamide nanocomposite reverse osmosis membrane, RSC Adv. 3 (2013) 8203-8207.

[24] S.G. Kim, D.H. Hyeon, J.H. Chun, B.H. Chun, S.H. Kim, Nanocomposite poly (arylene ether sulfone) reverse osmosis membrane containing functional zeolite nanoparticles for seawater desalination, J. Membr. Sci. 443 (2013) 10-18.

[25] M.M. Pendergast, A.K. Ghosh, E.M.V. Hoek, Separation performance and interfacial properties of nanocomposite reverse osmosis membranes, Desalination 308 (2013) 180-185.

[26] M. Bao, G. Zhu, L. Wang, M. Wang, C. Gao, Preparation of monodispersed spherical mesoporousnanosilica-polyamide thin film composite reverse osmosis membranes via interfacial polymerization, Desalination 309 (2013) 261-266.

[27] S.G. Kim, J.H. Chun, B.H. Chun, S.H. Kim, Preparation, characterization and performance of poly(aylene ether sulfone)/modified silica nanocomposite reverse osmosis membrane for seawater desalination, Desalination 325 (2013) 76-83.

[28] G.N.B. Baroña, J. Lim, M. Choi, B. Jung, Interfacial polymerization of polyamide-aluminosilicate SWNT nanocomposite membranes for reverse osmosis, Desalination 325 (2013) 138-147

[29] H. Zhao, S. Qiu, L. Wu, L. Zhang, H. Chen, C. Cao, improving the performance of polyamide reverse osmosis membrane by incorporating of modified multi wall carbon nanotubes, Journal of membrane science, 450 (2014) 249-256

[30] M. Ghanbaria, D. Emadzadeh, W. J. Lau, T. Matsuura, and A. F. Ismail, Synthesis and characterization of novel thin film nanocomposite reverse osmosis membranes with improved organic fouling properties for water desalination, RSC adv 5 (2015) 21268-21276

[31] N. Rakhshan, M. Pakizeh, The effect of chemical modification of $\mathrm{SiO}_{2}$ nanoparticles on the nanofiltration characteristics of polyamide membrane, journal of chemical engineering,32 (2015) 2524-2533

[32] H. Dong, L. Wu, L. Zhang, H. Chen, C. Cao, Clay nano-sheet as charged filler materials for highperformance and fouling resistance Thin film nanocomposite membrane, Journal of membrane science 494 (2015) 92-103

[33] M. Safarpour, A. Khataee, V. Vatanpour, thin film nanocomposite reverse osmosis membrane modified by reduced graphene oxide/ $\mathrm{TiO} 2$ with improved desalination performance, journal of membrane science 489 (2015) 43-54

[34] D. Emadzadeh, W. J. Lau, R. Rahbara, A. Danseshfar, A. Mayahi, T. Matsuura, A. F. smail, A novel thin film nanocomposite reverse osmosis membrane with superior anti organic fouling affinity for water desalination, desalination, 368 (2015) 106-113

[35] S. Bano, A. Mahmood, S. Kim, K. Lee, graphene oxide modified polyamide nanofiltration membrane with improved flux and antifouling properties, J. M. Chemistry 3 (2015) 2065-2071 
[36] A. S. Al Hobibi, J. Ghoul, I. Chiloufi, L. EL Mir, synthesis and characterization of polyamide thin film nanocomposite membrane reached by aluminum doped $\mathrm{ZnO}$, Material science in semiconductor processing 42 (2016) 111-114

[37] L. Liu, G. Zhu, Z. Liu, C. Gao, effect of MCM-48 nanoparticles on the performance of TFN membrane for reverse osmosis application, desalination 394 (2016) 72-82

[38] J. Yin, B. Deng, Graphene oxide enhanced polyamide thin-film nanocomposite membrane for water purification, Desalination 379 (2016) 93-101

[39] J. D. Nikolova, M. A. Islam, Contribution to adsorbed layer resistance to flux decline in ultrafiltration process, Journal of Membrane Science., 146 (1998) 105-111

[40] P. K. Lee, C. T. Arnot, D. Mattia, A review of reverse osmosis membrane materials for desalinationdevelopment to date and future potential, Journal of Membrane Science, 370 (2011) 1-22

[41] D. Rana, Y. Kim, T. Matsuura, H. Arafat, development of antifouling thin film composite membrane for sea water desalination, Journal of Membrane Science, 367 (2011) 110-11

Citation: A. Mayyahi \& Hamid Al Asadi, "Reverse Osmosis Polyamide Thin Film Nanocomposite Membranes for Water Desalination: A Study", International Journal of Advanced Research in Chemical Science (IJARCS), vol. 4, no. 8, pp. 7-13, 2017. http://dx.doi.org/10.20431/2349-0403.0408002

Copyright: (C) 2017 Authors. This is an open-access article distributed under the terms of the Creative Commons Attribution License, which permits unrestricted use, distribution, and reproduction in any medium, provided the original author and source are credited. 